\title{
Farklı insansız hava araçlarından (İHA) elde edilen veriler ile buğday bitkisinin boyunun belirlenmesi
}

\section{Determination of the height of the wheat plant with the data obtained from different unmanned aerial vehicles (UAVs)}

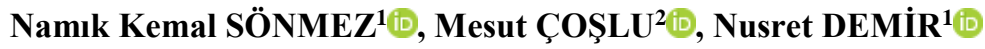 \\ ${ }^{1}$ Akdeniz Üniversitesi, Fen Fakültesi, Uzay Bilimleri ve Teknolojileri Bölümü, 07070, Antalya \\ ${ }^{2}$ Akdeniz Üniversitesi, Uzaktan Algılama Araştırma ve Uygulama Merkezi (AKUZAL), 07070, Antalya \\ Sorumlu yazar (Corresponding author): N. K. Sönmez, e-posta (e-mail): nksonmez@akdeniz.edu.tr \\ Yazar(lar) e-posta (Author e-mail): mesutcoslu@akdeniz.edu.tr, nusretdemir@akdeniz.edu.tr
}

\section{MAKALE BİLGİSI}

Alınış tarihi 09 Kasım 2020

Düzeltilme tarihi 09 Şubat 2021

Kabul tarihi 19 Mart 2021

\section{Anahtar Kelimeler:}

İnsansiz hava aracı

Buğday

Bitki boyu

Normalize edilmiş sayısal yüzey modeli

\begin{abstract}
ÖZ
Bu çalışmada farklı özelliklere sahip insansız hava araçları kullanılarak (İHA), üç ayrı tarihte çekimi yapılan makarnalık buğday çeşidinin bitki boylarının yarı otomatik olarak hesaplanması amaçlanmıştır. Çalışma, Akdeniz bölgesi için uzaktan algılama çalışmalarında en uygun tarih olarak kabul edilen ve buğdayın vejetatif dönemden generatif döneme geçtiği nisan ayında gerçekleştirilmiştir. İnsansız hava aracı verileri nisan ayı içerisindeki üç farklı tarih aralığında temin edilmiş olup, İHA çekimleri ile eş zamanlı olarak arazide yersel ölçümler de yapılmıştır. İnsansız hava araçlarından alınan veriler $10 \mathrm{~m}$ yükseklikten ve uygun bindirme oranları ile elde edilmiştir. Tüm hava fotoğrafları ortomozaik görüntü, sayısal yüzey modeli (DSM) ve sayısal arazi modeli (DTM) üretimi amacıyla aynı prosedürler uygulanarak işlenmiștir. Çalıșmada çok yüksek çözünürlüklü ortomozaik görüntüler üzerinden denemelere ait parsel sınırları belirlenirken, DSM ve DTM verileri kullanılarak elde edilen normalize edilmiş sayısal yüzey modeli (nDSM) ile bitki boyları hesaplanmıştır. Çalışma sonunda yarı otomatik olarak hesaplanan bitki boyları, aynı alandaki araziden ölçülen bitki boyları ile karşılaştırılmıştır. Hesaplanan bitki yükseklik değerleri ile arazi ölçüm değerleri arasında yapılan istatistiksel analizler sonucunda en yüksek ilişkiler, Phantom 3 Advanced İHA'sı için (r=0.948) 16 Nisan 2020 tarihinde, Mavic Pro İHA'sı için (r=0.886) 10 Nisan 2020 tarihinde ve Inspire 2 İHA's1 için ise $(r=0.924) 22$ Nisan 2020 tarihinde elde edilmiștir. Araștırma sonucuna göre, bitki boyunun farklı özelliklere sahip insansız hava araçları ile güvenli bir şekilde belirlenebileceği ortaya konmuştur.
\end{abstract}

\section{ARTICLE INFO}

Received 09 November 2020

Received in revised form 09 February 2021 Accepted 19 March 2021

\section{Keywords:}

Unmanned aerial vehicle

Wheat

Plant height

Normalized digital surface model

\section{ABSTRACT}

In this study, it is aimed to calculate the plant height of durum wheat variety on three different dates using unmanned aerial vehicles (UAV) with different characteristics semi-automatically. The study was carried out in April, which is the period when wheat passes from vegetative to generative period and which is also considered the most suitable date in remote sensing studies for the Mediterranean region. Unmanned aerial vehicle data were obtained in three different date intervals in April, and ground measurements were made simultaneously with the UAV shots. The data obtained from the unmanned aerial vehicles were taken from a height of $10 \mathrm{~m}$ and with appropriate overlap ratios. All aerial photographs were processed using the same procedures for the production of orthomosaic images, digital surface models (DSM) and digital terrain models (DTM). In the study, while determining the parcel boundaries of the trials on very highresolution orthomosaic images, plant heights were calculated with the normalized digital surface model (nDSM) obtained by using DSM and DTM data. At the end of the study, the plant heights calculated semi-automatically were compared with the plant heights measured in the field in the same area. As a result of the statistical analysis between the calculated plant height values and field measurement values, the highest correlation was found $(\mathrm{r}=0.948)$ for Phantom 3 Advanced UAV on April 16, 2020; (r= 0.886) for Mavic Pro UAV on April 10, 2020; (r=0.924) for Inspire 2 UAV on April 22, 2020. According to the result of the research, it has been revealed that the plant height can be determined safely with unmanned aerial vehicles with different characteristics. 


\section{Giriş}

Dünya nüfusundaki hızlı artış beraberinde gıda maddelerindeki tüketim artışına da neden olmaktadır. $\mathrm{Bu}$ artış küresel anlamda gıda talebinin 40 yıl daha artacağı anlamına gelmektedir. Artan bu gıda talebinin karşılanmasında tarımda sürdürülebilirlik ve hassas tarım uygulamaları önem arz etmektedir (Godfray ve ark. 2010).

Tarımsal üretimde bitki gelişiminin izlenmesi hassas tarımda kullanılan yaygın bir uygulama olup, özellikle bitki büyümesinin gözlemlenmesi, birim zaman ve birim alan başına kaynakların verimli kullanılması ve üretim sırasında verimi etkileyecek değişimlere zamanında müdahale edilmesi en önemli hedeflerdendir. Ayrıca, hassas tarım uygulamaları, üretimi ve üretimde karı artırmanın yanı sıra çevresel etkilerden kaynaklı oluşabilecek zararları da önleyebilmektedir (Panda ve ark. 2010; Dong ve ark. 2019).

Son y1llarda gerek askeri gerekse akademik ve ticari anlamda İHA sensörlerinin gelişiminde kat edilen mesafe, bu cihazların tarımdan turizme pek çok alanda kullanılmasına imkân tanımaktadır. İnsansız hava araçları üzerinde yer alan bu sensörlerin entegrasyonundaki kolaylıklar ve bu sayede elde edilen yüksek mekânsal çözünürlüklü veriler en önemli avantajlarındandır. Günümüzde İHA tabanlı uzaktan algılama çalışmalarında her ne kadar hiperspektral kameralara yer verilse de genellikle RGB kameralar kullanılmaktadır. Bu kapsamda İHA'lar ile özellikle RGB görüntülere dayalı ağaç tacı belirleme, bitki büyümesinin izlenmesi ve değişim analizlerinde güvenilir sonuçlar üretilebilmektedir. (Yao ve Chen 2019).

Düşük maliyeti ve çok yönlülüğü nedeniyle yaygın olarak kullanılan RGB görüntülerin işlenmesindeki en yaygın tekniklerden biri olan Structure from Motion (SfM) fotogrametrisi, üst üste binen görüntülerden yüksek çözünürlüklü üç boyutlu topografik veya yapısal rekonstrüksiyon sunan yeni bir yöntemdir. İnsansız hava aracından elde edilen görüntülerin, SfM ve Multi-View Stereo (MVS) dahil olmak üzere fotogrametrik yöntemler kullanılarak işlenmesi ile üç boyutlu nokta bulutları, ortomozaik görüntüler, DSM'ler ve DTM'ler üretilebilir. Bu veriler, tarımsal üretim alanlarında bitki ya da ağaçların karakterizasyonunu belirlemek amaciyla kullanılan verilerin temelini oluşturmaktadır (Westoby ve ark. 2012; Dong ve ark. 2019).

Bitkide boy ölçümü ile elde edilen yükseklik bilgisi özellikle verim ve yatmaya dayanıklılığın belirlenmesinde önemli bir göstergedir. Standart manuel yöntemlerle bitki boyu ölçümü hem yoğun emek isteyen hem de zaman alıcı bir işlemdir. Bu nedenle son yıllarda bitki boylarının hesaplanmasında düşük maliyetli ve anlık görüntüler temin edilebilen insansız hava aracı sistemleri sıkça kullanılmaktadır (Holman ve ark. 2016; Demir ve ark. 2018; Hu ve ark. 2018).

Arpa ve pirinç bitkilerinin boylarını modellemek ve hesaplamak için İHA tabanlı SfM yöntemlerinin uygulandığ araştırma bulgularına göre, arpanın yersel ölçüm değerleri ile yapılan karşılaştırmalar sonucu, üç farklı tarihte $0.55,0.22$ ve 0.71 regresyon katsayısı değerleri elde edilmiştir. Araştırmacılar, bitki yüksekliği belirlemede hatanın ana kaynağı olarak GPS doğruluğunu işaret etmekte ve görüntü toplama için daha yüksek kaliteli kameraların kullanılmasını önermektedirler (Bendig ve ark. 2013a; Bendig ve ark. 2013b).

Sabit kanatlı bir İHA görüntülerinden sorgum bitkisinin yüksekliğinin ölçülmesinde $120 \mathrm{~m}$ yükseklikten alınan görüntüler kullanılarak İHA tabanlı tahminler ile yer gerçeği verileri arasında güçlü ilişkiler $\left(\mathrm{R}^{2}=0.80\right)$ tespit edilmiştir. Ayrıca bu çalışmada araştırmacılar tarafından kullanılan çok seviyeli yer kontrol noktaları (YKN) ile Karekök Ortalama Hatasının (RMSE) \%20 düştüğü tespit edilmiştir. Bu bulgular neticesinde YKN tabanlı yükseklik kalibrasyonunun, özellikle gelecekteki uygulamalar için önemli bir potansiyele sahip olduğu değerlendirilmiştir (Han ve ark. 2018).

Buğday bitkisinde büyüme aşamaları genellikle zadoks ölçeği ile ifade edilir ve bu dönemlerde izlenecek bitki boyu değerleri o bölgede yetişen çeşidin yetiştirilme koşullarının belirlenmesinde önemli rol oynamaktadır (Holman ve ark. 2016; Zadoks ve ark. 1974). Buğdayda bitki boyunun hesaplanmasında IHHA ve LIDAR verilerinin karşılaştırıldığ araştırmacılar LIDAR için $\mathrm{R}^{2}$ değerini 0.97 olarak bulurken, İHA verilerinden elde edilen değeri de 0.91 olarak tespit etmişlerdir. Araştırmacılar bu çalışma için döner kanatlı İHA olan, Matrice 600 Pro (M600) ve Phantom 3 Pro kullanmışlardır (Yuan ve ark. 2018). İnsansız hava aracı tabanlı uzaktan algılama teknolojisi ile farklı buğday çeşitlerinde farklı azot uygulamalarında bitki boyunun daha hızlı ve doğru bir şekilde elde edilebilmesi amacıyla İngiltere'de bir çalışma gerçekleştirilmiştir. Çalışma kapsamında SfM fotogrametrisi kullanılmış ve manuel ölçüm değerleri ile karşılaştırıldığında yüksek doğruluk $\left(R^{2}=\geq 0.92\right.$, $\mathrm{RMSE}=\leq 0.07 \mathrm{~m}$ ) elde edilmiştir. Araştırmacılar çalışma sonuçlarına göre, genel olarak kullanılan yöntemin mahsul denemelerinde veya daha genel tarımsal uygulamalarda kullanım için çok yüksek çözünürlükte ve doğrulukta bitki boylarının hızlı yüksek verimli tarla içi fenotiplemesi için değerli bir araç olma potansiyeline sahip olduğunu belirtmişlerdir (Holman ve ark. 2016). Demir ve ark. (2018) buğday bitkisinde İHA fotogrametrisi ile bitki yüksekliğinin belirlendiği çalışmalarında elde edilen bulguların geleneksel yöntem ile oldukça ilişkili olduğunu tespit etmişlerdir.

Farklı İHA'lara monte edilmiş kameralardan buğdayda yarı otomatik bitki boyu hesaplanması amacı ile yürütülen bu çalışma, makarnalık buğday çeşidini içeren bir deneme alanında gerçekleştirilmiştir. Çalışma kapsamında üç farklı tarihte üç farklı İHA'dan alınan veriler kullanılarak üretilen nDSM'den bitki boyları yarı otomatik olarak hesaplanmıştır. Araştırma sonucunda İHA'lar ile elde edilen bitki boyları, yersel ölçüm değerleri ile karşılaştırılmış ve farklı İHA'lar kullanılarak belirlenen yükseklik değerleri ile yer gerçekleri arasında bitkinin farklı dönemleri için istatistiksel olarak önemli ilişkiler bulunmuştur.

\section{Materyal ve Yöntem}

\section{1. Çalışma alanı}

$\mathrm{Bu}$ çalışma 2020 yılında Antalya ilinde yer alan Akdeniz Üniversitesi $\left(36^{\circ} 54^{\prime}\right.$ Kuzey enlemleri ile 30³8' Doğu boylamlarında) Ziraat Fakültesi araştırma ve uygulama arazisindeki makarnalık buğday çeşidinin yer aldığı deneme parsellerinde yürütülmüştür. Çalışma alanı 21 parselden oluşmaktadır. Makarnalık buğday çeşidinin yer aldığı parsellerin her biri 2.5x5 m boyutundadır (Şekil 1).

Çalışmada, makarnalık buğday çeşidinde deneme konuları arasındaki varyasyonu en üst seviyeye ulaştırmak amacıyla farklı dozlarda azot uygulaması yapılmış ve deneme tesadüf blokları deneme desenine göre üç tekerrürlü olarak planlanmıştır. Bu kapsamda çalışma alanında bitki boyunu önemli oranda etkileyecek hiç azot verilmeyen ve altı farklı azot uygulaması yapılan deneme parselleri oluşturulmuştur. Deneme öncesi araziden toprak örnekleri alınmış ve yapılan laboratuvar 


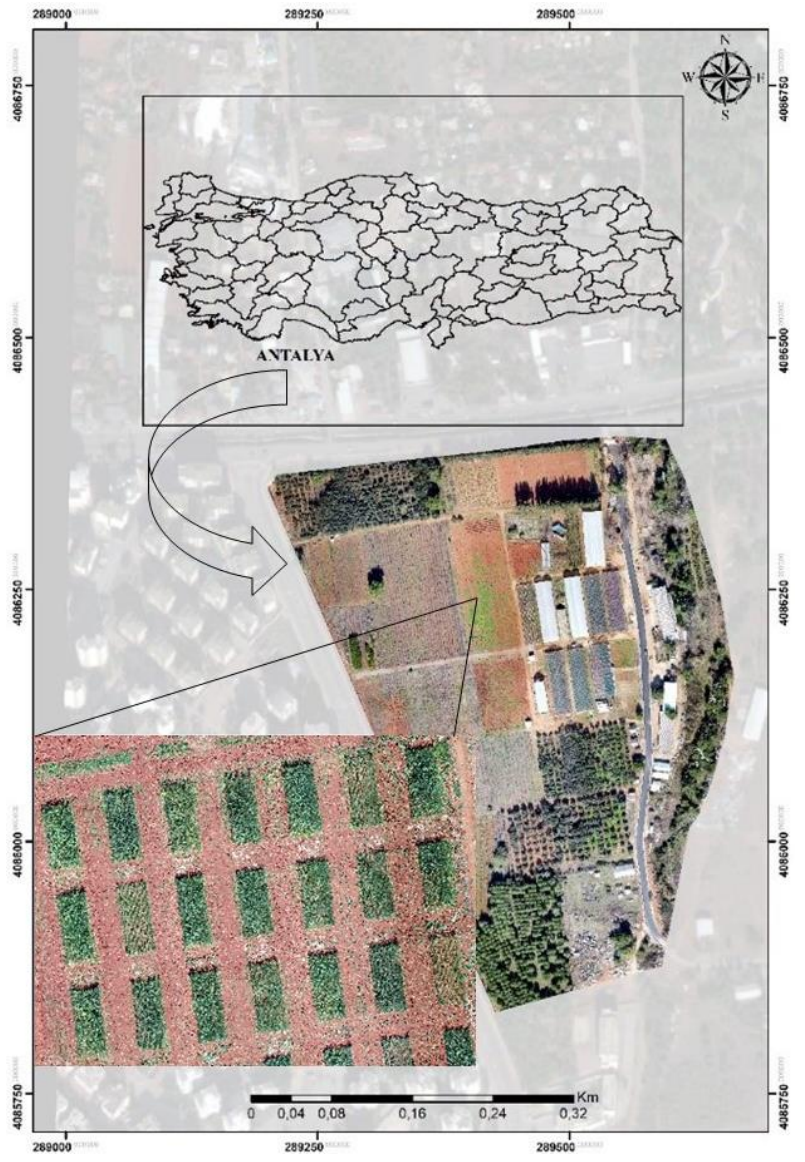

analizlerine göre, gerekli gübreleme işlemi yapılmıştır. Bitkiye ait azot uygulaması işlemi ise bitki gelişim periyodu boyunca ve hesaplanan farklı dozlarda uygulama şeklinde yapılmıştır.

\section{2. Çalışmada kullanılan veriler}

Çalışmada materyal olarak tarımsal uygulamalarda son yıllarda yaygın olarak kullanılan insansız hava araçları tercih edilmiştir. Bu kapsamda Şekil 2'de de görüleceği üzere deneme, yüksek çözünürlüklü verilerin temin edilmesine olanak tanıyan ve üzerlerinde farklı özelliklere sahip üç kamera bulunan insansız hava araçları ile yürütülmüştür.

Çalışmada kullanılan İHA'lardan ilki 1280 gr ağırlığa ve yaklaşık $23 \mathrm{dk}$ uçuş süresine ve $12 \mathrm{MP}$ kameraya sahip olan DJI Phantom 3 Advanced aracidır. Bitki boyunun belirlenmesinde kullanılan ikinci İHA ise, yaklaşık 734 gr ağırlığında olan ve yaklaşık 27 dakika havada kalabilen ve 12 MP kameraya sahip DJI Mavic Pro insansız hava aracıdır. Çalışmada kullanılan son insansız hava aracı ise maksimum kalkış ağırlığı 4250 gr olan, 20 MP kamera sensörüne sahip ve 27 dakika havada kalabilen Inspire 2 insansız hava aracıdır. Söz konusu araçlar ve bu araçlara monte edilen kameraların teknik özelikleri ile işlem ayarları Çizelge 1'de detaylı olarak verilmiştir.

Yürütülen bu çalışmada kullanılan insansız hava araçlarından elde edilen temel veriler ile alana ait güncel sayısal yüzey modeli (DSM), sayısal arazi modeli (DTM) ve yüksek çözünürlüklü ortomozaik görüntüler üretilmiştir. $\mathrm{Bu}$ verilerin işlenmesinde materyal olarak Pix4D yazılımı kullanılmıştır.

Şekil 1. Çalışma alanı.

Figure 1. Study area.

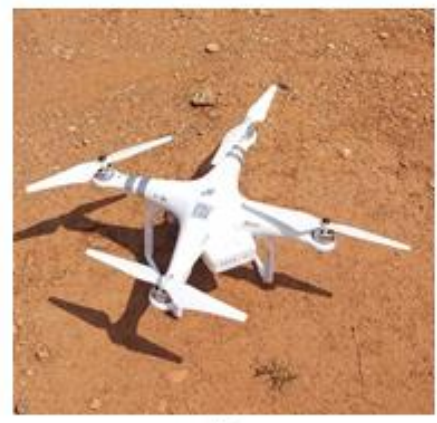

(a)

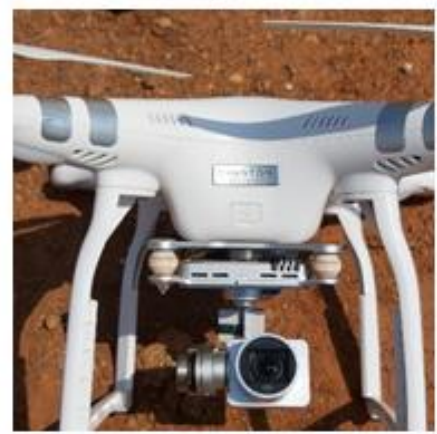

(d)

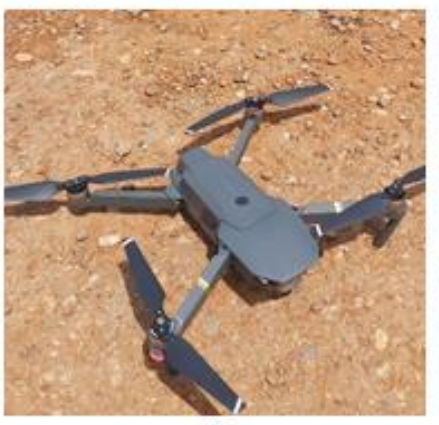

(b)

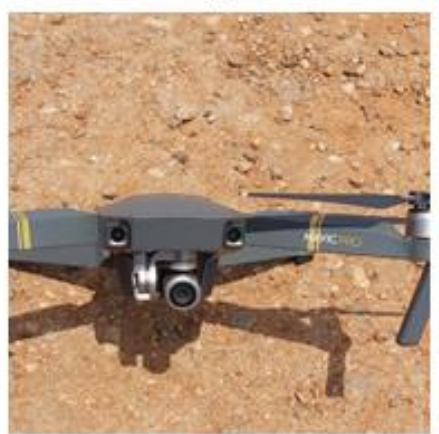

(e)

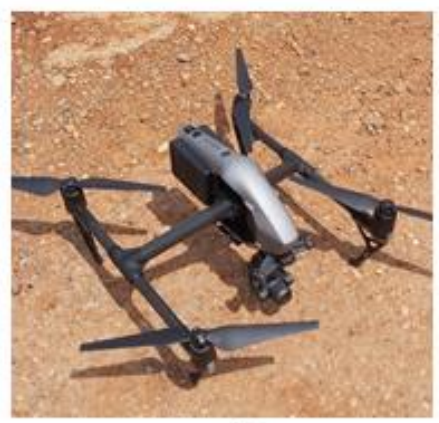

(c)

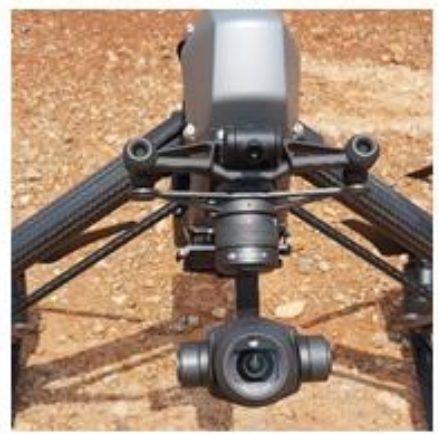

(f)

Şekil 2. Çalışmada kullanılan İHA ve kameralar, Phantom 3 Advanced (a, d); Mavic Pro (b, e); Inspire 2 (c, f).

Figure 2. UAVs and cameras used in the study, Phantom 3 Advanced (a, d); Mavic Pro (b, e); Inspire 2 (c, f). 
Yarı otomatik olarak belirlenen bitki boylarının değerlendirilmesinde yersel ölçümlerden elde edilen bitki boyu ölçüm değerleri referans alınmıştır. Her bir deneme konusu için arazide yapılan yersel ölçümler, bir şeritmetre yardımı ile topraktan itibaren bitkinin en uç kısmı dikkate alınarak gerçekleştirilmiştir. Araştırma bulgularının istatistiksel analizinde ve CBS ortamına aktarılmasında ArcGIS ve SAS yazılımları kullanılmıştır.

\subsection{Yöntem}

Akdeniz Üniversitesi Ziraat Fakültesi deneme parsellerinde makarnalık buğday bitkisinin sağlıklı büyüyerek dane veriminin en üst düzeyde olmasını sağlamak amaciyla sulama ve gübreleme gibi uygulamaların bilimsel koşullar altında yürütüldügü bu çalışma, dört temel aşamadan oluşmaktadır. Bunlar, üç farklı dönem için İHA verilerinin temin edilmesi, İHA verilerinin işlenmesi, elde edilen DSM ile DTM kullanılarak nDSM üretilmesi ve değerlendirme aşamalarıdır (Şekil 3). Çalışmanın değerlendirme aşamasında, doğruluk analizinde kullanılmak üzere bitki boylarının yersel ölçüm değerleri her dönem için manuel olarak belirlenmiştir.
Çalışma kapsamında makarnalık buğday bitkisinin Akdeniz bölgesinde vejetatif dönemden generatif döneme geçtiği nisan ayı tercih edilmiş olup, bu ay içerisindeki üç farklı tarih aralığında uçuşlar gerçekleştirilmiştir. Bu tarihin belirlenme nedeni Epiphanio ve ark. (1990) tarafindan da belirtildiği üzere, buğday ile ilgili yürütülen uzaktan algılama çalışmalarının bu gelişim döneminde yüksek başarı elde edilmesinden dolayıdır. Pek çok araştırmacı da bu uzaktan algılama çalışmalarında buğday bitkisinin vegetatif dönemden generatif döneme geçtiği ayın tercih edilmesinin uygun olduğunu belirtmiştir. $\mathrm{Bu}$ kapsamda, çalışmada verilerin temin edilmesi amacı ile deneme parsellerinde 10 Nisan 2020, 16 Nisan 2020 ve 22 Nisan 2020 tarihlerinde üç farklı İHA ile 10 m yükseklikten uygun üst ve yan bindirme oranları ile fotoğraf çekimleri işlemi gerçekleştirilmiştir. İnsansız hava aracı uçuşları öncesinde, çekilecek fotoğrafların konumsal doğruluklarının artırılması amacıyla çalışma alanında homojen olarak belirlenmiş beş adet yer kontrol noktası (YKN) tesis edilmiştir (Şekil 4a). Belirlenen bu noktaların koordinat ve yükseklik değerleri ölçülerek Coğrafi Bilgi Sistemleri (CBS) ortamına aktarılmıştır.

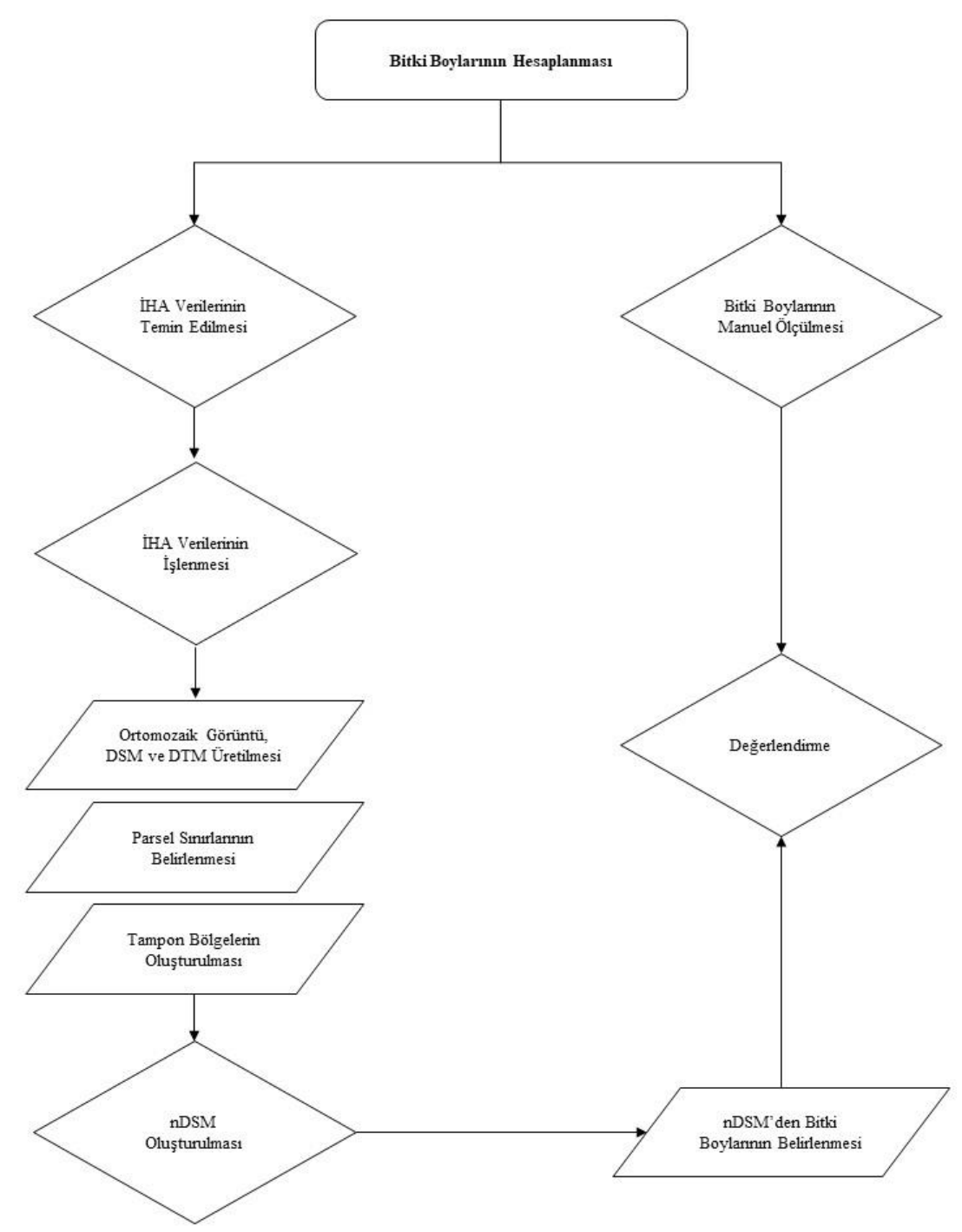

Şekil 3. İş akış şeması.

Figure 3. Flowchart. 
Çalışmanın değerlendirme aşamasında kullanılmak üzere İHA uçuşları ile eş zamanlı olarak 10 Nisan 2020, 16 Nisan 2020 ve 22 Nisan 2020 tarihlerinde şeritmetre kullanılarak buğday bitkilerinin boy ölçümleri manuel olarak yapılmıştır (Şekil 4b).

Çalışmanın ikinci aşamasında İHA'lardan elde edilen fotoğraflar, görüntüleri yapılandırmak için sıkça kullanılan hareketten yapı (Structure from Motion-SfM) ve çoklu görüş stereo (Multi-View Stereo-MVS) yaklaşımları ile Pix4D yazılımı kullanılarak alana ait ortomozaik görüntü, DSM ve DTM oluşturulmuştur.

$\mathrm{Bu}$ işlem için Pix4D yazılımında İHA ile çekilmiş bir dizi görüntüden 3 boyutlu bir model üretilebilmesi için önce SfM daha sonra MVS işlemleri gerçekleştirilmiştir. Bu aşamanın ilk alt adımında, bağlantı noktaları oluşturmak üzere Pix4Dmapper yazılımı tarafindan otomatik olarak tüm görüntülerde mevcut olan belirli özellikler (keypoint) dikkate alınarak eşleştirme işlemi gerçekleştirilmiş ve görüntüler hizalanmıştır. Bu aşamanın ikinci alt adımında ise yoğunlaştırılmış bir nokta bulutu ve üç boyutlu dokulu bir ağ üretilmiştir. Son olarak daha önce oluşturulan nokta bulutuna dayalı olarak ters mesafe ağırlıklandırma yöntemi ile bir DSM oluşturulmuştur. Çalışmanın bu aşamasında DSM'e ek olarak ortorektifiye edilmiş bir ortomozaik görüntü ile Pix4Dmapper yazılımındaki ek modül kullanılarak DSM'e dayalı bir DTM oluşturulmuştur. DTM'nin yer örneklem mesafesi (GSD), ortomozaik görüntünün GSD'sinin Pix4Dmapper yazılımında optimum değer olarak yer alan 5 katına ayarlanmıştır. Son alt işlem adımında üretilen DSM, Ortomozaik görüntü ve DTM'ye ait parametre ve ayarlar Çizelge 1 'de verilmiştir.

Çalışmanın bir diğer aşamasında ise, coğrafi bilgi sistemleri ortamında alana ait veri tabanları oluşturulmuş ve İHA verilerinden elde edilen yüksek çözünürlüklü ortomozaik görüntü üzerinde parsellerin sinırları vektör veri formatında tanımlanmıştır. Daha sonra, hesaplanan değerler ile yer gerçekleri arasında sağlıklı ilişkilerin kurulması amacı ile her parsele ait birim alanlar oluşturulmuştur.

Çalışmanın üçüncü aşamasında, makarnalık buğday parsellerine ait her bir veri seti için mevcut DSM ve DTM verileri ile Eşitlik 1 kullanılarak nDSM verisi elde edilmiş ve daha önce oluşturulan her parsele ait tampon bölge için bitki boyları yarı otomatik olarak hesaplanmıştır.

$$
n D S M=D S M-D T M
$$

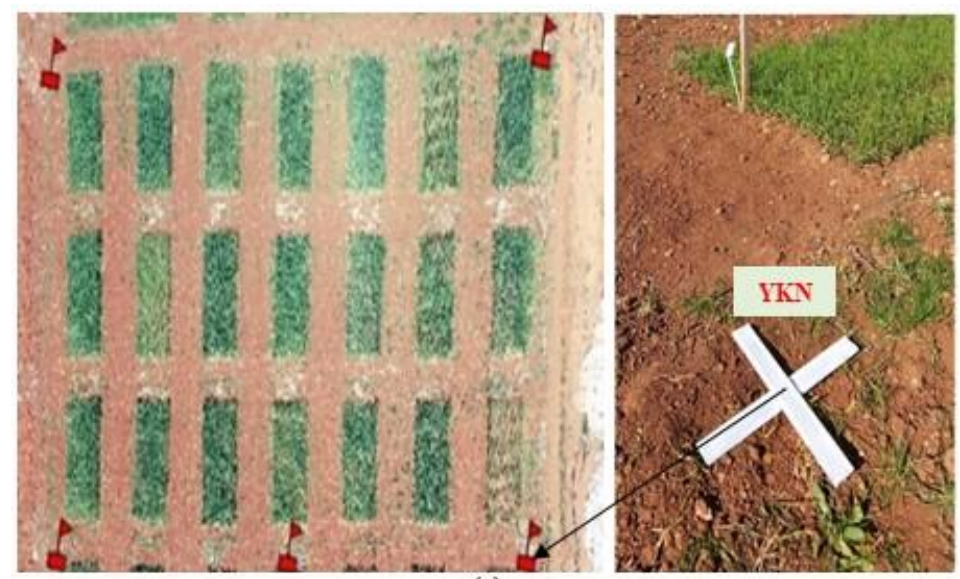

(a)

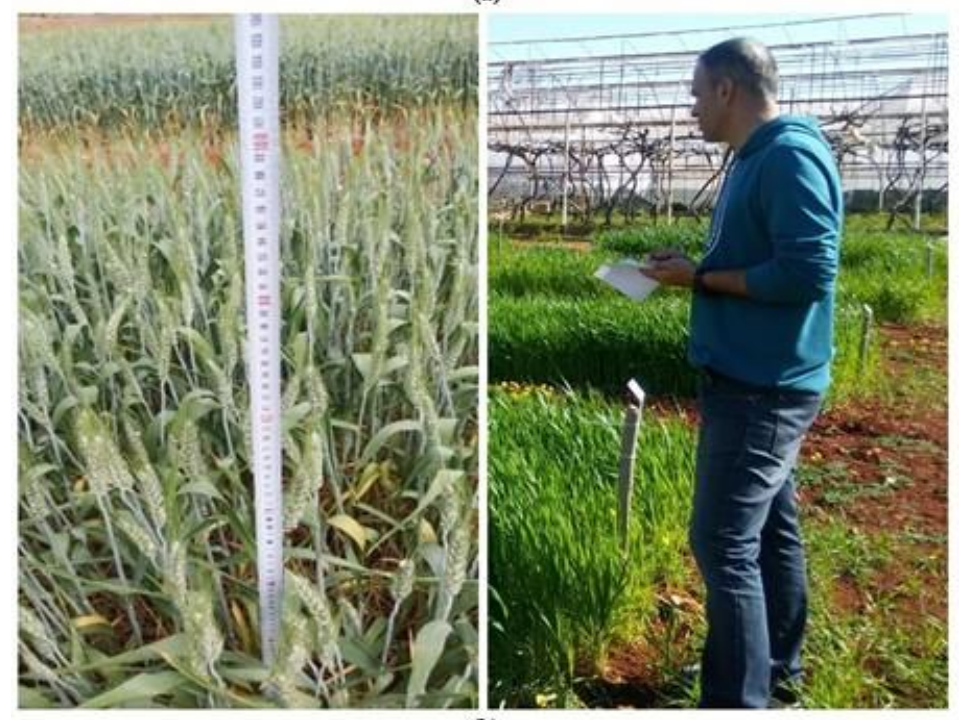

(b)

Şekil 4. Yer kontrol noktaları (a) ve bitki boylarının manuel ölçülmesi (b).

Figure 4. Ground control points (a) and manual measurement of plant height (b). 
Çizelge 1. Çalışmada kullanılan İHA'ların özellikleri (DJI 2020a; DJI 2020b; DJI 2020c; DJI 2020d) ve DSM, ortomozaik, DTM işlem ayarları Table 1. Features of the UAVs used in the study (DJ 2020a; DJI 2020b; DJI 2020c; DJ 2020d) and DSM, orthomosaic, DTM process settings

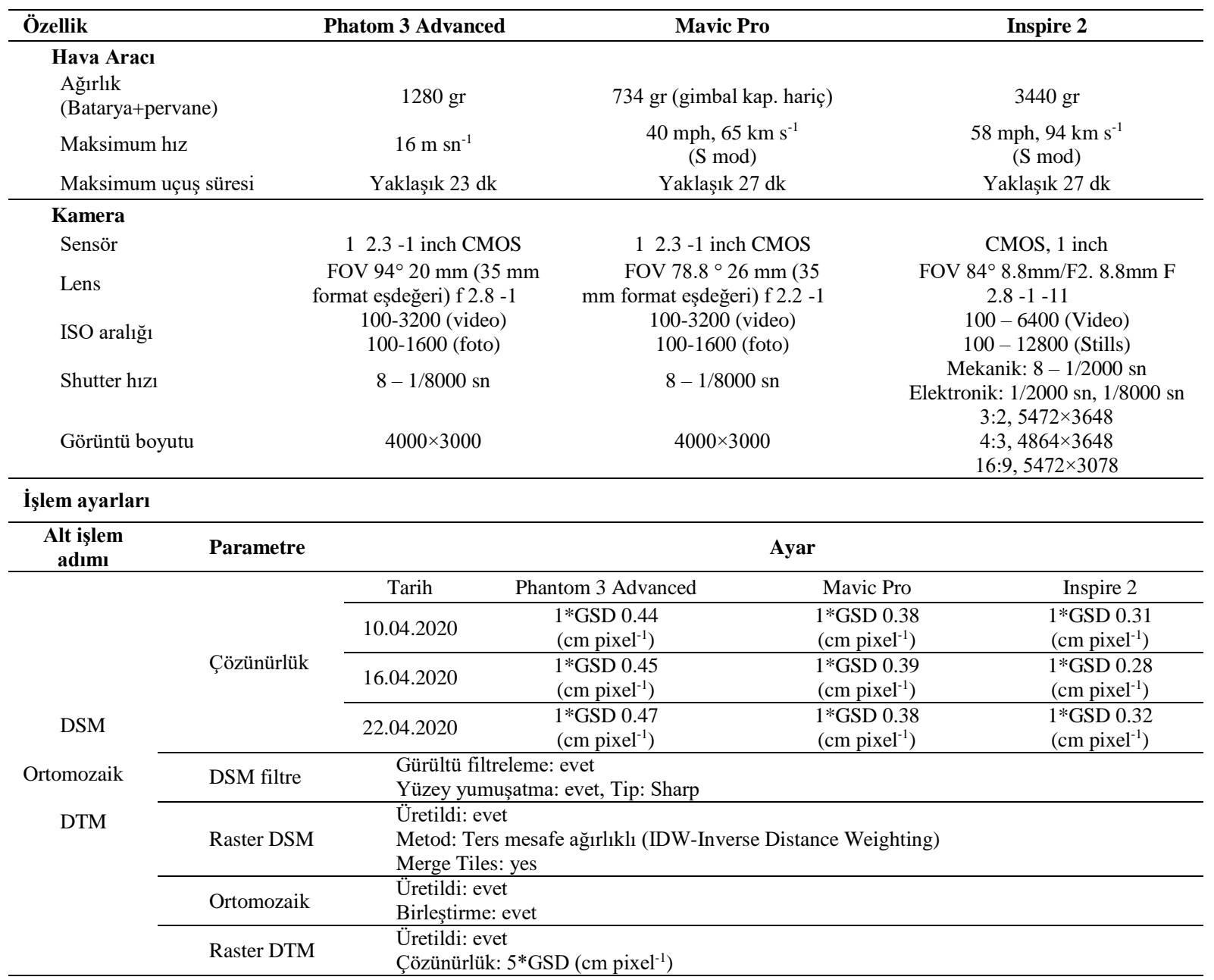

Çalışmanın son aşamasında ise her bir parsele ait hesaplanan bitki boyları ile aynı alanda eş zamanlı olarak gerçekleştirilen yersel ölçüm değerleri arasındaki ilişkiler istatistiksel olarak değerlendirilmiştir. İstatistiksel analizler kapsamında gerçekleştirilen doğrusal regresyon analizlerinde $\mathrm{r}$ (Pearson'ın korelasyon katsayısısı) değerinin hesaplanmasında aşağıda verilen Eşitlik 2 kullanılmıştır.

$$
r=\frac{\sum_{i=1}^{n}\left(x_{i-} \bar{x}\right)\left(y_{i-} \bar{y}\right)}{(n-1) S_{x} S_{y}}
$$

Pearson'ın korelasyon katsayısısı eşitliğinde yer alan $x_{i}$, i gözleminin $\mathrm{x}$ değişkenine ait değerini; $\bar{x}, \mathrm{x}$ değişkenine ait örneklem ortlamasını; $S_{x}$, x değişkenine ait örneklem standart sapmasını; $y_{i}$, i gözleminin y değişkenine ait değerini; $\bar{y}, \mathrm{y}$ değişkenine ait örneklem ortlamasını; $S_{y}, \mathrm{y}$ değişkenine ait örneklem standart sapmasını ve $n$ de gözlem sayısını göstermektedir.

İki değişken arasında ilişki olduğunun istatistiksel olarak anlamlı kabul edilebilmesi için $r_{i s t} \geq t_{\alpha}$ koşulunun sağlanması gerekir (Çubukçu 2015). Bu kapsamda Pearson'ın korelasyon katsayısının istatiği $\left(\mathrm{r}_{\text {ist }}\right)$ Eşitlik 3 ile hesaplanmıştır.

$$
r_{i s t}=r \sqrt{\frac{n-2}{1-r^{2}}}
$$

Burada $r_{i s t}$, Pearson'ın korelasyon katsayısının istatistiği; $r$, Pearson'ın korelasyon katsayısı ve $n$ ise gözlem sayısıdır.

\section{Bulgular ve Tartışma}

Farklı özelliklere sahip insansız hava araçları ile bitki boylarının hesaplandığı bu çalıșmada öncelikli olarak ortomozaik görüntülerin oluşturulması işlemi gerçekleştirilmiş olup, ardından alana ait sayısal yüzey modelleri (DSM) ile sayısal arazi modelleri (DTM) hesaplanmıştır. Bu kapsamda üç insansız hava aracı için üretilen ortomozaik görüntü, DSM ve DTM Şekil 5'te verilmiştir.

Ayrıca bu aşamada CBS ortamında üretilen vektör veri formatındaki parsel sınırları ve ArcGIS yazılımında yer alan "data management/features/feature to point" arac1 kullanilarak bu parsellerin orta noktaları belirlenmiştir (ESRI 2021a). Belirlenen bu parsel orta noktalarının yarı otomatik boy ölçüm değerlerinin hesaplanacağ $120 \mathrm{~cm}$ 'lik çapta tampon bölgeler ise yine ArcGIS yazılımında "analysis/proximity/buffer" aracı ile oluşturulmuştur (ESRI 2021b). 
Şekil 5'te gösterilen söz konusu bu alanlarda, farklı insansız hava araçlarından hesaplanan DSM ve DTM verilerini birbirinden çıarmak suretiyle nDSM verileri oluşturulmuş ve her parsele ait tampon bölge için bitki boyları yarı otomatik olarak hesaplanmıştır. Söz konusu hesaplanan nDSM verileri, parsel sınırları ve tampon bölgeler Şekil 6'da verilmiştir.

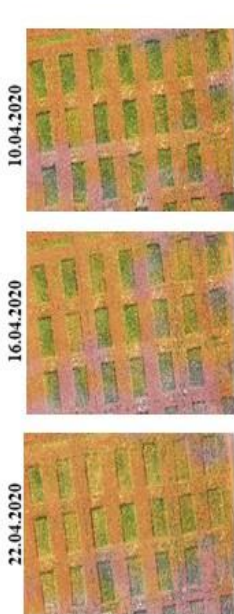

(a)
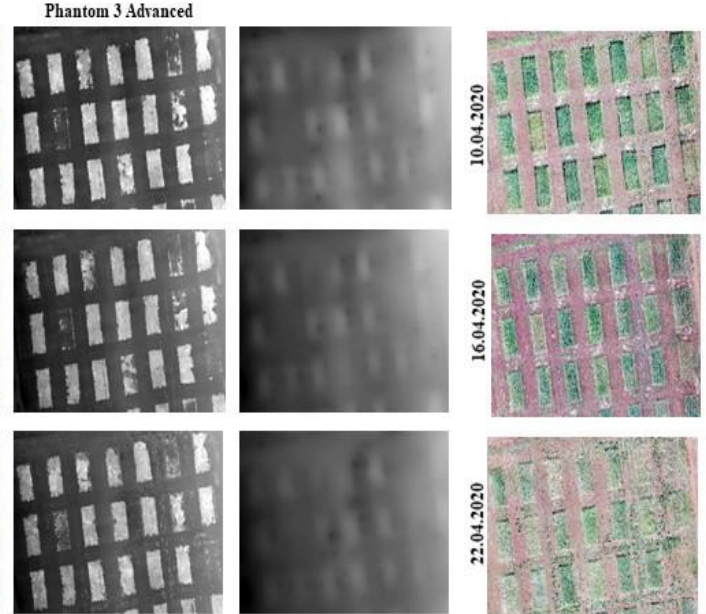

(b)

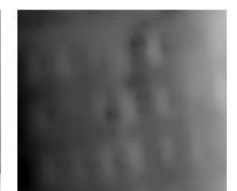

(c)

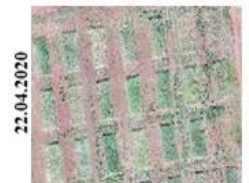

(a)
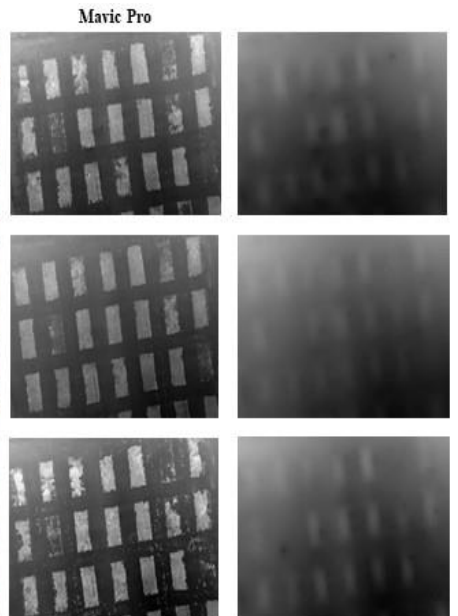

(b)

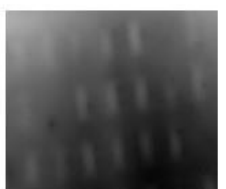

(c)

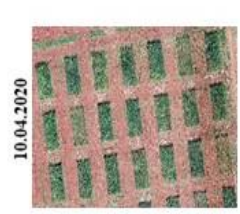

Inspire 2
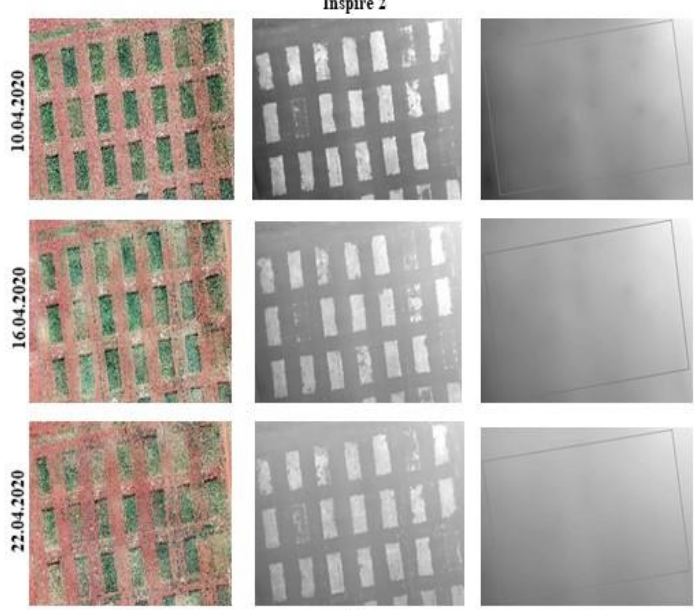

(b)

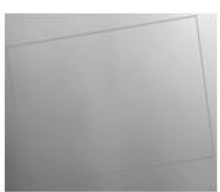

(a)

(c)

Şekil 5. İnsansız hava araçlarından elde edilen ortomozaik (a), DSM (b), ve DTM (c) görüntüler

Figure 5. Orthomosaic (a), DSM (b), and DTM (c) images obtained from unmanned aerial vehicles

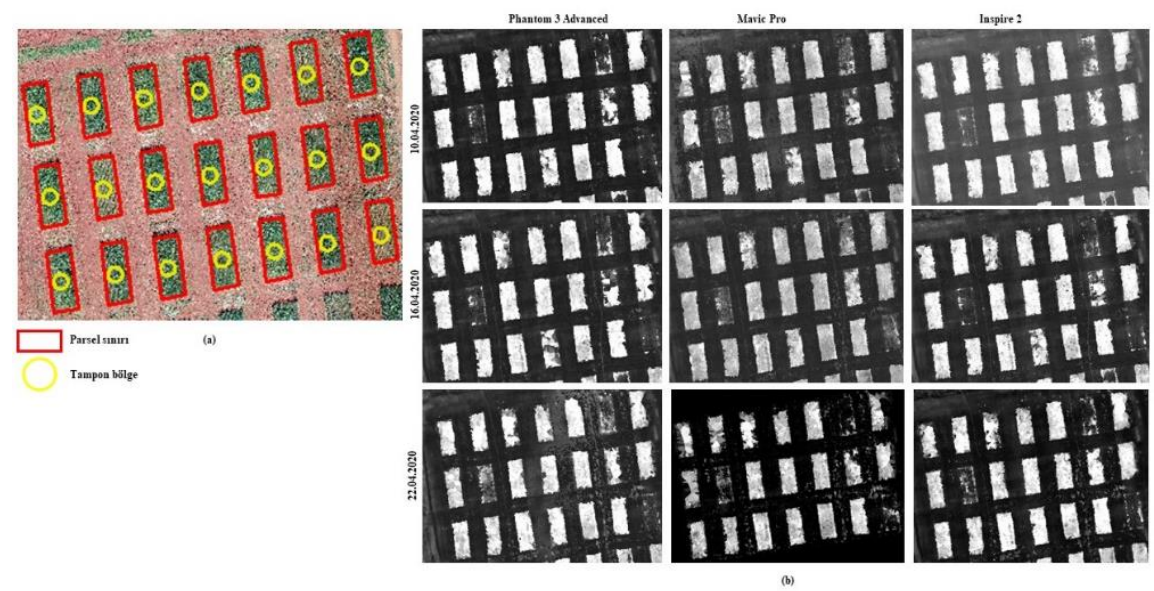

Şekil 6. Parsel sınırları, tampon bölgeler (a) ve normalize edilmiş sayısal yüzey modelleri (b)

Figure 6. Plot boundaries, buffer zones (a) normalized digital surface models 
Çalışmada elde edilen veri setlerinin tamamında uygulanan korelasyon analizlerinde yaygın ismi Pearson'ın çarpım-moment korelasyon katsayısı olarak bilinen Pearson'ın korelasyon katsayısı hesaplanmıştır. Daha sonra Pearson'ın korelasyon katsayısının istatistiksel olarak anlamlılık durumunu belirlemek amaciyla hesaplanan $r_{\text {ist }}$ değeri $\% 95$ güven düzeyinde $(\alpha=0.05)$ test edilmiştir $\left(t_{\alpha}=2.571\right)$. Bu kapsamda, 10 Nisan 2020, 16 Nisan 2020 ve 22 Nisan 2020 tarihli nDSM görüntüleri kullanılarak birim alandaki bitkilerin boyları karşılaştırılmıştır. Araştırma sonuçlarına göre, Phantom 3 Advanced İHA'sından elde edilen bu bitki boyları manuel olarak ölçülen yersel değerler ile karşılaştırıldığında en yüksek $r$ değeri $0.948\left(r_{i s t}=6.664\right)$ ile 16 Nisan 2020 tarihli görüntüden elde edilirken, en küçük r değeri $0.893\left(r_{i s t}=4.449\right)$ ile 22 Nisan 2020 tarihli görüntüden elde edilmiştir.

Yarı otomatik bitki boyu hesaplamasında kullanılan diğer bir İHA olan Mavic Pro'dan alınan verilerde en yüksek $r$ değeri $0.886\left(r_{i s t}=4.279\right)$ ile 10 Nisan 2020 tarihli görüntüden elde edilirken, en küçük $r$ değeri ise $0.824\left(r_{i s t}=3.252\right)$ ile 16 Nisan 2020 tarihli görüntüden elde edilmiştir.

Çalışmada kullanılan ve pek çok özellik bakımından diğer iki İHA'ya nazaran daha üst seviyede yer alan Inspire 2 ile, diğer iki İHA'dan farklı olarak makarnalık buğday parsellerinde en yüksek $r$ değeri 0.924 ( $\left.r_{i s t}=5.412\right) 22$ Nisan 2020 tarihinde, en düşük $r$ değeri ise $0.859\left(r_{i s t}=3.753\right)$ ile 16 Nisan 2020 tarihinde tespit edilmiştir.

Çizelge 2'den de görüleceği üzere, farklı İHA'lar kullanılarak elde edilen değerler için, makarnalık buğdayın nisan ayındaki üç farklı tarih aralığında bitki boyunun belirlenmesinde yüksek oranda ilişkiler tespit edilmiştir. Araştırma bulgularından elde edilen sonuçlara göre en düşük ilişki $\left(r=0.824, r_{i s t}=3.252\right)$ ile 16 Nisan 2020 tarihli Mavic Pro ile elde edilmiştir. Tüm tarihlerde alanda tespit edilen en yüksek ilişki ise ( $r=0.948, r_{i s t}=$ 6.664) 16 Nisan 2020 tarihindeki Phantom 3 Advanced insansiz hava aracı ile gerçekleştirilen hesaplamadan elde edilmiştir.

Çalışmada kullanılan tüm İHA'lar için hesaplanan r istatistiği değerlerinin eşik değerinden $\left(t_{\alpha}=2.571\right)$ yüksek olmas1 nedeniyle Pearson'ın korelasyon katsayılarının \%95 güven düzeyinde anlamlı ve iki değişken arasında istatistiksel açıdan pozitif bir ilişki olduğu belirlenmiştir.

\section{Sonuç}

Farklı insansız hava araçlarının bitki boyu hesaplanmasındaki başarısının test edildiği bu çalışmada farklı azot uygulamasının yapıldığı deneme konularına sahip makarnalık buğday çeşidinde, üç farklı tarihte ve üç farklı kamera ile $10 \mathrm{~m}$ yükseklikten yarı otomatik olarak elde edilen bitki boyu ölçüm değerlerinin manuel olarak temin edilen yersel ölçüm değerleri ile karşılaştırılması gerçekleştirilmiştir.

$\mathrm{Bu}$ araştırma sonucunda İHA ile elde edilen bitki boyları, yersel ölçüm değerleri ile karşılaştırılmış ve hesaplanan yükseklik değerleri ile yer gerçekleri arasında istatistiksel olarak önemli ilişkiler bulunmuştur. Elde edilen bu bulgular Holman ve ark. (2016); Hu ve ark. (2018); Demir ve ark. (2018); Su ve ark. (2019) gibi pek çok araştırmacı ile paralellik göstermekte olup, farklı özelliklere sahip insansız hava araçlarının tamamında bitki boyu hesaplamalarının güvenli bir şekilde yapılabileceği bu çalışmada ortaya konmuştur. Ayrıca, Çoşlu ve Sönmez (2019) tarafindan makarnalık buğdayda gerçekleştirilen bir başka çalışmada, nDSM'den elde dilen bulgular ile yer gerçekleri arasında bu çalışma ile benzer şekilde istatistiksel olarak önemli ilişkiler belirlenmiştir. Çalışma sonucunda elde edilen bulgulara göre, Akdeniz bölgesinde makarnalık buğday bitkisinin boyunun belirlenmesinde 12 MP kamera özelliğine sahip olan Phantom 3 Advanced insansız hava aracının daha başarılı sonuçlar verdiği bu çalışmanın önemli bir sonucudur. Nitekim çalıșmanın kalite raporundan edilen sonuçlar da, fotogrametrik blok dengelemede kök ortalama kare hatasının genel olarak özellikle z değeri için Inspire 2 İHA'sında diğerlerine göre daha yüksek olduğu belirlenmekle birlikte her ne kadar $120 \mathrm{~cm}$ çapındaki 45216 $\mathrm{cm}^{2}$ 'lik bir daire alanına Inspire 2 İHA'sından 50 görüntü pikseli girse de, Phantom 3 Advanced İHA'sından elde edilen görüntüde 22 pikselin girmesine rağmen yapılan korelasyon analizinde Phantom 3 Advanced İHA'sının kullanıldığı standart kameradan hesaplanan bitki boyu değerlerinin istatistiksel olarak ön plana çıkmasını desteklemektedir. Ayrıca aynı rapora göre Mavic serisi kameranın odak noktası tutarsızlık değerinin diğer İHA'lara göre düşük olması, genel anlamda Mavic serisinden hesaplanan bitki boyu değerlerindeki anlamlılık seviyesindeki istatistiksel düşüklüğ̈̈ de açıklar niteliktedir.

Çalışmada kullanılan üç farklı insansız hava aracında hesaplanan bitki boyu değerleri istatistiksel olarak üç farklı tarihte de önemli düzeyde anlamlı sonuçlar vermiş olsa bile çalışmadan elde edilen bu sonuçların farklı bitki ve farklı topoğrafyalarda denenerek test edilmesi gelecek çalışmalar için önerilmektedir.

Çizelge 2. Korelasyon analiz sonuçları

Table 2. Correlation analysis results

\begin{tabular}{|c|c|c|c|c|c|c|c|}
\hline \multirow{2}{*}{ Dönem } & \multirow{2}{*}{$\mathbf{t}_{\alpha} *$} & \multicolumn{2}{|c|}{ Phantom 3 Advanced } & \multicolumn{2}{|c|}{ Mavic Pro } & \multicolumn{2}{|c|}{ Inspire 2} \\
\hline & & $\mathrm{r} *$ & $\mathrm{r}_{\text {ist }} *$ & $\mathrm{r} *$ & $\mathrm{r}_{\text {ist }} *$ & $\mathrm{r} *$ & $\mathrm{r}_{\text {ist }}$ * \\
\hline 10.04 .2020 & & 0.898 & 4.554 & 0.886 & 4.279 & 0.889 & 4.345 \\
\hline 16.04 .2020 & 2.571 & 0.948 & 6.664 & 0.824 & 3.252 & 0.859 & 3.753 \\
\hline 22.04 .2020 & & 0.893 & 4.449 & 0.834 & 3.378 & 0.924 & 5.412 \\
\hline
\end{tabular}

*r: Pearson'ın korelasyon katsayısi; $\mathrm{r}_{\text {ist }}$ r $\mathrm{r}$ istatistiği; $\mathrm{t}_{\alpha}$ : eşik değer

\section{Kaynaklar}

Bendig J, Willkomm M, Tilly N, Gnyp ML, Bennertz S, Qiang C, Miao Y, Lenz-Wiedemann VIS, Bareth G (2013a) Very high resolution crop surface models (CSMs) from UAV-based stereo images for rice growth monitoring in Northeast China. International Archives of the Photogrammetry, Remote Sensing and Spatial Information Sciences 45-50.
Bendig J, Bolten A, Bareth G (2013b) UAV-based imaging for multitemporal, very high resolution crop surface models to monitor crop growth variability. Photogrammetrie Fernerkundung Geoinformation 551-562.

Çoşlu M, Sönmez NK (2019) Normalize edilmiş sayısal yüzey modeli (nDSM) ile bitki boyu ölçümü ve verim ilişkisi. II. International 
Eurasian Agriculture and Natural Sciences Congress, Vol.1 No.1 Antalya, s. 271-278.

Çubukçu KM (2015) Planlamada ve Coğrafyada Temel İstatistik ve Mekânsal İstatistik, Nobel Akademik Yayıncılık, Yayın No: 1097, Ankara.

Demir N, Sönmez NK, Akar T, Ünal S (2018) Automated measurement of plant height of wheat genotypes using a DSM derived from UAV. Imagery Proceedings 2, pp. 350.

DJI (2020a) Phantom 3 Advanced Specs. https://www.dji.com/phantom3-adv/info. Accessed 10 September 2020.

DJI (2020b) Mavic Pro Specs. https://www.dji.com/mavic/info. Accessed 10 September 2020.

DJI (2020c) Inspire 2 Specs. https://www.dji.com/inspire-2/info. Accessed 10 September 2020.

DJI (2020d) Zenmuse X4S spec. https://www.dji.com/zenmuseX4s/info\#specs. Accessed 10 September 2020.

Dong X, Zhang Z, Yu R, Tian Q, Zhu X (2010) Extraction of information about individual trees from high-spatial-resolution UAV-acquired 1mages of an orchard. Remote Sensing 12(1): 133.

Epiphanio JCN, Formaggio AR, Franca GV (1990) Evaluation of Landsat-5 TM Bands in discriminating between wheat and bean crops. Pesquisa Agropecua'ria Brasilerira, 25(3): 371-377.

ESRI (2021a) ArcMAP User manual, https: //desktop.arcgis.com/en/ arcmap /10.5/tools/data-management-toolbox/feature-to-point.htm. Accessed 27 January 2021.

ESRI (2021b) ArcMAP User manual, https: //desktop.arcgis.com/en /arcmap/latest/tools/analysis-toolbox/buffer.htm. Accessed 27 January 2021.

Godfray HCJ, Beddington JR, Crute IR, Haddad L, Lawrence D, Muir JF, Pretty J, Robinson S, Thomas SM, Toulmin C (2010) Food security: The challenge of feeding 9 billion people. Science 327: 812-818.
Han X, Thomasson JA, Bagnall GC, Pugh NA, Horne DW, Rooney WL, Jung J, Chang A, Malambo L, Popescu SC, Gates IT, Cope DA (2018) Measurement and calibration of plant-height from fixed-wing UAV Images. Sensors 18: 4092.

Holman FH, Riche AB, Michalski A, Castle M, Wooster MJ, Hawkesford MJ (2016) High throughput field phenotyping of wheat plant height and growth rate in field plot trials using UAV based remote sensing. Remote Sensing 8: 1031.

Hu P, Chapman S, Wang X, Potgieter A, Duan T, Jordan D, Guo Y, Zheng B (2018) Estimation of plant height using a high throughput phenotyping platform based on unmanned aerial vehicle and selfcalibration: Example for sorghum breeding. European Journal of Agronomy 95: 24-32.

Panda SS, Hoogenboom G, Paz JO (2010) Remote sensing and geospatial technological applications for site-specific management of fruit and nut crops: A review. Remote Sensing 2: 1973-1997.

Su W, Zhang M, Bian D, Liu Z, Huang J, Wang W, Wu J, Guo H (2019) Phenotyping of corn plants using unmanned aerial vehicle (UAV) images. Remote Sensing 11: 2021.

Westoby MJ, Brasington J, Glasser NF, Hambrey MJ, Reynolds JM (2012) Structure-from-motion photogrammetry: A low-cost, effective tool for geoscience applications. Geomorphology 179: 300314.

Yao H, Qin R, Chen X (2019) Unmanned aerial vehicle for remote sensing applications-A review. Remote Sensing 11: 1443.

Yuan W, Li J, Bhatta M, Shi Y, Baenziger PS, Ge Y (2018) Wheat height estimation using LIDAR in comparison to ultrasonic sensor and UAS. Sensors 18(11): 3731.

Zadoks JC, Chang TT, Konzak CF (1974) A decimal code for the growth stages of cereals. Weed Research 14: 415-421. 